\title{
Chemical analysis and in vitro antioxidant and anticholinesterase activities of essential oils and extracts from different parts of Erica manipuliflora
}

\author{
Çiğgem KUŞ ${ }^{1}$ (D), Meltem TAŞ ${ }^{1}$ (D), Selçuk KÜÇÜKAYDIN ${ }^{2}$ (D) , Gülsen TEL-ÇAYAN ${ }^{3}$ (D), \\ Mehmet Emin DURU 1* (iD) \\ 1 Department of Chemistry, Faculty of Sciences, Muğla Sıtkı Koçman University, Muğla 48000, Turkey. \\ 2 Department of Medical Services and Techniques, Köyceğiz Vocational School of Health Services, Muğla Sitk1 \\ Koçman University, Muğla 48000, Turkey. \\ 3 Department of Chemistry and Chemical Processing Technologies, Muğla Vocational School, Muğla Sitkı Koçman \\ University, Muğla 48000, Turkey. \\ * Corresponding Author. E-mail: eminduru@mu.edu.tr (M.E.D); Tel. +90-252-212 1494.
}

Received: 22 April 2019 / Revised: 30 September 2019 / Accepted: 05 October 2019

ABSTRACT: This study reports the chemical composition of essential oils and in vitro antioxidant and anticholinesterase activities of essential oils, hexane, ethyl acetate, methanol, and butanol extracts of aerial, flower and leaves parts of Erica manipuliflora. GC and GC/MS analyses were used for identification of essential oils. Totals of 47 compounds were detected in the essential oils of aerial, flower and leaves parts accounting for $99.99 \%, 99.88 \%$ and $99.97 \%$, respectively. The major components of the aerial, flower and leaves parts of essential oils were Germacren D $(14.76 \%, 15.55 \%$ and $13.58 \%)$, tau-cadinol $(7.53 \%, 4.11 \%$ and $8.96 \%)$, caryophyllene oxide $(3.92 \%, 5.17 \%$ and $8.55 \%), \beta$ caryophyllene $(7.24 \%, 5.97 \%$ and $7.73 \%)$, and a-terpineol $(6.85 \%, 6.14 \%$ and $4.18 \%)$, respectively. The essential oils of aerial $(34.49 \%)$ and leaves (37.01\%) parts consisted of mainly sesquiterpene hydrocarbons whereas essential oil of flower part $(42.58 \%)$ included monoterpenoids. The essential oils and extracts were screened for their antioxidant and anticholinesterase activities. The results of activities showed that extracts possessed the highest antioxidant activity while essential oils had the highest anticholinesterase activity. This finding supposes that E. manipuliflora may be considered as valuable natural source with antioxidant and anticholinesterase properties for food, cosmetic and pharmaceutical industries.

KEYWORDS: Erica manipuliflora; chemical composition; essential oil; extracts; different parts; antioxidant activity; anticholinesterase activity.

\section{INTRODUCTION}

The genus Erica L. is a member of the family Ericaceae and more than 800 species naturally grow in the world, mainly in the coastal areas of the Mediterranean Sea [1-4]. Erica species which are narrow-leaved and evergreen in winter have a wide variety of flower structures and colours. Erica species are called as "funda", "püren" or "süpürge çalısı" locally in Turkey. Totally 5 species are reported in Turkey; namely, E. arborea, E. manipuliflora, E, bocquetii, E. sicula subsp. libanotica and E. spiculifolia salisb. E, bocquetii is endemic to South Western Anatolia (between Elmalı and Fethiye region) [3, 5-7]. Erica manipuliflora is the most common Erica species in southwest part of Turkey. Since ancient times, Erica species have been used as a traditional medicine for the treatment of burns and wounds by the local people in Anatolia. The studies have been showed that Erica species possess antiulcer [8,9], antimicrobial [10,11], antibacterial, cytotoxic [12-15] and antioxidant [1620] activities. It has also been reported that Erica species have (poly) phenolic, flavonoid, coumarin and triterpenoid, compounds [21-28]. According to our knowledge, there is no study in the literature on anticholinesterase activity and chemical composition of essential oil of E. manipuliflora growing in Turkey.

The aim of this study was to investigate the antioxidant and anticholinesterase activities of hexane, ethyl acetate, methanol, butanol extracts obtained from aerial, flower, and leaves parts of E. manipuliflora which is widely grown in Anatolia and used for various purposes by the local people. In addition, determination of chemical composition, antioxidant and anticholinesterase activities of essential oil obtained via hydrodistillation of aerial, flower, and leaves parts of the plant were aimed.

How to cite this article: Kuş Ç, Taş M, Küçükaydın S, Tel-Çayan G, Duru ME. Chemical analysis and in vitro antioxidant and anticholinesterase activities of essential oils and extracts from different parts of Erica manipuliflora. J Res Pharm. 2019; 23(6): 1098-1105. 


\section{RESULTS AND DISCUSSION}

\subsection{Chemical composition of essential oils}

The essential oils obtained from aerial, flower and leaves parts of E. manipuliflora were analyzed using the GC and GC-MS techniques. The chemical compositions of the essential oils, relative percentages (\%) and Kovats index of compounds are presented in Table 1. A total of 47 components were detected in each of the three parts of essential oils, and all of them were identified. The main compounds of the aerial, flower and leaves parts of essential oils were Germacren D $(14.76 \%, 15.55 \%$ and $13.58 \%)$, tau-cadinol $(7.53 \%, 4.11 \%$ and $8.96 \%)$, caryophyllene oxide $(3.92 \%, 5.17 \%$ and $8.55 \%), \beta$-caryophyllene $(7.24 \%, 5.97 \%$ and $7.73 \%)$, and aterpineol $(6.85 \%, 6.14 \%$ and $4.18 \%)$, respectively (Table 1$)$.

Sesquiterpene hydrocarbons were the most abundant compounds in aerial $(34.49 \%)$ and leaves $(37.01 \%)$ parts of essential oils while monoterpenoids were found to be most abundant compounds in flower part (42.58\%) of essential oil.

In a previous report, the essential composition of E. manipuliflora collected from two different regions of Greece was studied and Heptacosane, caryophyllene oxide, $\beta$-caryophyllene, 1-octen-3-ol, a-terpineol and linanol were recorded as main compounds [29]. The similarities and differences were found in the chemical composition of the essential oils of Erica species when our results were compared to literature findings.

\subsection{Antioxidant activity}

The antioxidant activities of essential oils, hexane, ethyl acetate, methanol and butanol extracts obtained from aerial, flower and leaves parts of E. manipuliflora were tested with five different assays i.e. $\beta$-carotenelinoleic acid, DPPH radical scavenging, ABTS cation radical scavenging, cupric-reducing antioxidant capacity (CUPRAC) and metal chelating activity. The results are showed in Table 2. The antioxidant capacities compared with a-tocopherol, BHA, and EDTA. The essential oils and extracts were tested at different concentrations and $\mathrm{IC}_{50}$ values were determined.

The highest lipid peroxidation inhibition activity by $\beta$-carotene-linoleic acid was detected in flower part of ethyl acetate extract of E. manipuliflora with the $\mathrm{IC}_{50}$ value of $45.61 \pm 1.28 \mu \mathrm{g} / \mathrm{mL}$ followed by leaves part of ethyl acetate extract $\left(\mathrm{IC}_{50}: 48.16 \pm 1.35 \mu \mathrm{g} / \mathrm{mL}\right)$. It was determined that all studied samples had low lipid peroxidation inhibition activities than standards.

Radical scavenging activities of the samples were measured by monitoring the removal of $\mathrm{DPPH} \cdot$ radical at $515 \mathrm{~nm}$ and $\mathrm{ABTS}^{{ }^{+}+}$radical at $734 \mathrm{~nm}$. Antioxidants capture $\mathrm{DPPH}{ }^{\bullet}$ and $\mathrm{ABTS}^{\bullet+}$ radicals, cause to disappear of the colours of these radicals and decrease in the absorbance. In DPPH ${ }^{\bullet}$ assay, the aerial, flower and leaves parts of butanol extract exhibited the highest activity among the all studied extracts and essential oils. The flower part of butanol extract $\left(\mathrm{IC}_{50}: 35.64 \pm 1.15 \mu \mathrm{g} / \mathrm{mL}\right)$ indicated higher $\mathrm{DPPH} \bullet$ radical scavenging activity than a-tocopherol $\left(\mathrm{IC}_{50}: 37.20 \pm 0.41 \mu \mathrm{g} / \mathrm{mL}\right.$ ). In ABTS ${ }^{\bullet+}$ assay, the leaves part of methanol extract $\left(\mathrm{IC}_{50}\right.$ : $20.01 \pm 0.63 \mu \mathrm{g} / \mathrm{mL}$ ), and the aerial part of hexane extract $\left(\mathrm{IC}_{50}: 38.12 \pm 1.57 \mu \mathrm{g} / \mathrm{mL}\right.$ ) exhibited higher radical scavenging activities than a-tocopherol ( $\left.\mathrm{IC}_{50}: 38.51 \pm 0.54 \mu \mathrm{g} / \mathrm{mL}\right)$.

CUPRAC assay was used to evaluate reducing properties of the samples. The aerial $\left(\mathrm{A}_{0.05}: 15.47 \pm 0.05\right.$ $\mu \mathrm{g} / \mathrm{mL}$ ), flower $\left(\mathrm{A}_{0.05}: 12.77 \pm 0.04 \mu \mathrm{g} / \mathrm{mL}\right)$ and leaves $\left(\mathrm{A}_{0.05}: 10.22 \pm 0.06 \mu \mathrm{g} / \mathrm{mL}\right)$ parts of butanol extracts were found to be more active than BHA $\left(\mathrm{A}_{0.05}: 24.40 \pm 0.69 \mu \mathrm{g} / \mathrm{mL}\right)$ and a-tocopherol $\left(\mathrm{A}_{0.05}: 66.72 \pm 0.81 \mu \mathrm{g} / \mathrm{mL}\right)$ used as standards. Also, the aerial $\left(\mathrm{A}_{0.05}: 44.57 \pm 0.12 \mu \mathrm{g} / \mathrm{mL}\right)$, flower $\left(\mathrm{A}_{0.05}: 23.70 \pm 0.06 \mu \mathrm{g} / \mathrm{mL}\right)$ and leaves $\left(\mathrm{A}_{0.05}\right.$ : $49.78 \pm 0.06 \mu \mathrm{g} / \mathrm{mL}$ ) parts of methanol extract showed significant reducing activity (Table 2 ).

Another significant mechanism of measuring antioxidant activity is chelation of iron and transition metals (arsenic, copper, vanadium, chromium, cadmium, cobalt, nickel,). The highest ability to chelate ferrous ion was shown in the flower part of ethyl acetate extract with $27.45 \pm 1.25 \%$ inhibition at $400 \mu \mathrm{g} / \mathrm{mL}$ concentration and followed by the leaves part of essential oil $(21.33 \pm 1.88 \%)$. In general, the all studied samples exhibited low metal chelating activity (Table 2). In a recent study, the antioxidant capacities of various extracts (chloroform, ethyl acetate, methanol, butanol and water) of E. manipuliflora were investigated using 1,1diphenyl-2-picrylhydrazyl (DPPH•) radical scavenging and the thiobarbituric acid (TBA) test systems [30]. These results are consistent with previous studies on the antioxidant activity of Erica species.

\subsection{Anticholinesterase activity}

Alzheimer's disease (AD) is a cognitive disorder that occurs in association with aging and is widespread in recent years. 
Table 1. Chemical composition of the essential oils of aerial, flower and leaves parts of Erica manipuliflora.

\begin{tabular}{|c|c|c|c|c|c|c|}
\hline No & Compoundsa & $\begin{array}{c}\text { Aerial } \\
\text { part } \\
\left(\% \mathrm{~b}^{\mathrm{b}}\right) \\
\end{array}$ & $\begin{array}{c}\text { Flower } \\
\text { part }\left(\% 0^{b}\right)\end{array}$ & $\begin{array}{l}\text { Leaves part } \\
\qquad\left(\%^{\mathrm{b}}\right)\end{array}$ & RIc & $\begin{array}{l}\text { Identification } \\
\text { Methods }^{\mathrm{d}}\end{array}$ \\
\hline 1 & cis-Linalol oxide & 0.38 & 1.22 & 0.16 & 1078 & Co-GC, MS, RI \\
\hline 2 & Linalool & 1.12 & 4.17 & 0.72 & 1104 & Co-GC, MS, RI \\
\hline 3 & cis-Limonene oxide & 1.96 & 5.56 & 0.62 & 1124 & Co-GC, MS, RI \\
\hline 4 & $\beta$-Phenylethanol & $t r$ & 0.48 & $t r$ & 1136 & MS, RI \\
\hline 5 & Verbenone & 0.67 & 0.84 & 0.15 & 1141 & MS, RI \\
\hline 6 & a-Campholenal & 0.12 & 0.16 & $t r$ & 1145 & MS, RI \\
\hline 7 & trans-pinocarveol & 5.78 & 5.51 & 1.82 & 1150 & Co-GC, MS, RI \\
\hline 8 & cis-Verbenol & 0.34 & 0.57 & 0.11 & 1154 & MS, RI \\
\hline 9 & Borneol & 2.56 & 2.75 & 0.47 & 1168 & Co-GC, MS, RI \\
\hline 10 & Verbenol & 0.67 & 1.17 & 0.25 & 1172 & Co-GC, MS, RI \\
\hline 11 & $a$-Terpineol & 6.85 & 6.14 & 4.18 & 1178 & Co-GC, MS, RI \\
\hline 12 & Myrtenol & 0.98 & $t r$ & 1.51 & 1183 & Co-GC, MS, RI \\
\hline 13 & cis-Carveol & 0.43 & 0.53 & 0.20 & 1206 & Co-GC.MS. RI \\
\hline 14 & 2-Coumarone & 0.77 & 1.34 & 0.32 & 1224 & MS. RI \\
\hline 15 & trans-Geraniol & 2.63 & 3.2 & 0.86 & 1239 & Co-GC.MS. RI \\
\hline 16 & cis-7-Decenal & 0.40 & 0.48 & 0.85 & 1245 & MS, RI \\
\hline 17 & Mesitol & 0.24 & 0.31 & 0.32 & 1249 & MS, RI \\
\hline 18 & Benzocycloheptatrien & 0.57 & 1.05 & 0.14 & 1256 & MS, RI \\
\hline 19 & Carvacrol & 4.03 & 4.12 & 3.57 & 1262 & Co-GC, MS, RI \\
\hline 20 & Thymol & 0.02 & 1.43 & 0.55 & 1268 & Co-GC, MS, RI \\
\hline 21 & 2-Methoxy-4-vinylphenol & 0.59 & 0.96 & 0.12 & 1278 & MS, RI \\
\hline 22 & (E.E)-2.4-Decadienal & 0.75 & $t r$ & 0.45 & 1283 & MS, RI \\
\hline 23 & Eugenol & 0.22 & 0.67 & 0.3 & 1326 & Co-GC, MS, RI \\
\hline 24 & $\beta$-Bourbonene & 0.92 & 2.76 & 2.10 & 1332 & MS, RI \\
\hline 25 & cis-Jasmone & 2.91 & 2.71 & 2.09 & 1342 & Co-GC, MS, RI \\
\hline 26 & $\beta$-Caryophyllene & 7.24 & 5.97 & 7.73 & 1349 & Co-GC, MS, RI \\
\hline 27 & $\beta$-Cubebene & 1.39 & $t r$ & 1.10 & 1381 & MS, RI \\
\hline 28 & Germacrene D & 14.76 & 15.55 & 13.58 & 1464 & Co-GC, MS, RI \\
\hline 29 & $\beta$-İonone & 1.34 & 0.9 & 2.15 & 1467 & MS, RI \\
\hline 30 & $a$-Amorphene & 1.43 & 0.76 & 1.67 & 1471 & MS, RI \\
\hline 31 & $\delta$-Cadinene & 1.69 & 2.96 & 1.24 & 1495 & Co-GC, MS, RI \\
\hline 32 & $\beta$-İonol & 1.04 & 0.93 & 1.76 & 1485 & MS, RI \\
\hline 33 & $\beta$-Guaiene & 3.93 & 1.47 & 4.27 & 1491 & MS, RI \\
\hline 34 & Viridiflorene & 3.13 & 2.56 & 5.32 & 1494 & MS, RI \\
\hline 35 & Caryophyllene oxide & 3.92 & 5.17 & 8.55 & 1507 & Co-GC, MS, RI \\
\hline 36 & Viridiflorol & 4.52 & 1.38 & 7.01 & 1530 & MS, RI \\
\hline 37 & Isoaromadendrene epoxide & 0.95 & 1.36 & 2.50 & 1538 & MS, RI \\
\hline 38 & Spathulenol & 3.84 & 1.96 & 4.17 & 1556 & Co-GC, MS. RI \\
\hline 39 & tau-Cadinol & 7.53 & 4.11 & 8.96 & 1582 & MS, RI \\
\hline 40 & $a$-Cadinol & 3.38 & 3.30 & 4.59 & 1615 & MS, RI \\
\hline 41 & $a$-Hexylcinnamaldehyde & 0.54 & 0.83 & 0.41 & 1728 & MS, RI \\
\hline 42 & Benzyl benzoate & 0.54 & 0.83 & 0.97 & 1789 & MS, RI \\
\hline 43 & Salicylic acid benzyl ester & 0.63 & 1.18 & 0.43 & 1824 & MS, RI \\
\hline 44 & Heneicosane & 0.63 & $t r$ & 0.38 & 1935 & Co-GC, MS, RI \\
\hline 45 & 3-Deoxy.Estradiol & 0.8 & $\operatorname{tr}$ & 0.70 & 1955 & MS, RI \\
\hline 46 & Tricosane & 0.47 & 0.53 & 0.15 & 2091 & Co-GC, MS, RI \\
\hline \multirow[t]{8}{*}{47} & Heptacosane & 0.32 & $t r$ & 0.47 & 2295 & MS, RI \\
\hline & Monoterpene hydrocarbons & - & - & - & & \\
\hline & Monoterpenoids & 34.05 & 42.58 & 21.47 & & \\
\hline & Sesquiterpene hydrocarbons & 34.49 & 32.03 & 37.01 & & \\
\hline & Sesquiterpenoids & 24.68 & 18.11 & 36.19 & & \\
\hline & Others & 6.77 & 7.16 & 5.30 & & \\
\hline & Total identified (\%) & 99.99 & 99.88 & 99.97 & & \\
\hline & Total number of compounds & 47 & 47 & 47 & & \\
\hline
\end{tabular}

a Compounds are listed in order of their elution from a DB- 5 fused silica column. b Percentage concentration. c Retention index on DB-5 fused silica column. ${ }^{d}$ Identification methods: Co-I: Co-injection: based on comparison with authentic compounds; MS: based on comparison with WILEY, ADAMS and NIST 08 MS databases; RI: based on comparison of calculated with those reported in ADAMS and NIST 08. tr: trace 
Table 2. Antioxidant activities of the essential oil and extracts of aerial, flower and leaves parts of Erica manipufilora by $\beta$-Carotene-linoleic acid, DPPH ${ }^{\bullet}, \mathrm{ABTS}^{\bullet+}, \mathrm{CUPRAC}$ and metal chelating assaysa.

\begin{tabular}{|c|c|c|c|c|c|c|c|}
\hline \multicolumn{8}{|c|}{ Antioxidant Activity } \\
\hline & & & $\begin{array}{l}\beta \text {-Carotene- } \\
\text { linoleic } \\
\text { acid assay }\end{array}$ & $\begin{array}{l}\text { DPPH } \\
\text { assay }\end{array}$ & $\begin{array}{c}\text { ABTS•+ } \\
\text { assay }\end{array}$ & $\begin{array}{c}\text { CUPRAC } \\
\text { assay }\end{array}$ & $\begin{array}{c}\text { Metal } \\
\text { chelating } \\
\text { assay }\end{array}$ \\
\hline & & & $\begin{array}{c}\mathrm{IC}_{50} \\
(\mu \mathrm{g} / \mathrm{mL})\end{array}$ & $\begin{array}{c}\mathrm{IC}_{50} \\
(\mu \mathrm{g} / \mathrm{mL})\end{array}$ & $\begin{array}{c}\mathrm{IC}_{50} \\
(\mu \mathrm{g} / \mathrm{mL})\end{array}$ & $\begin{array}{c}A_{0.50} \\
(\mu \mathrm{g} / \mathrm{mL})^{c}\end{array}$ & $\begin{array}{c}\text { Inhibition } \\
\%^{\mathrm{b}}\end{array}$ \\
\hline \multirow{15}{*}{$\begin{array}{l}\text { Erica } \\
\text { manipuliflora }\end{array}$} & \multirow{3}{*}{$\begin{array}{l}\text { Essential } \\
\text { oil }\end{array}$} & APEs & $33.21 \pm 1.80^{\mathrm{b}}$ & $4.52 \pm 0.42^{b}$ & $11.28 \pm 1.79^{\mathrm{b}}$ & $0.095 \pm 0.16^{\mathrm{b}}$ & $\mathrm{NA}^{\mathrm{f}}$ \\
\hline & & FEs & $24.10 \pm 1.45^{\mathrm{b}}$ & $36.94 \pm 1.23$ & $9.90 \pm 0.61^{\mathrm{b}}$ & $0.102 \pm 0.01^{b}$ & $\mathrm{NA}^{\mathrm{f}}$ \\
\hline & & LEs & $43.20 \pm 1.20^{\mathrm{b}}$ & $6.17 \pm 0.18^{b}$ & $8.57 \pm 0.45^{\mathrm{b}}$ & $0.099 \pm 0.36^{\mathrm{b}}$ & $21.33 \pm 1.88$ \\
\hline & \multirow{3}{*}{ Hexane } & $\mathrm{APH}$ & $165.73 \pm 1.78$ & $>400$ & $38.12 \pm 1.57$ & $>400$ & $\mathrm{NA}^{\mathrm{f}}$ \\
\hline & & $\mathrm{FH}$ & $>400$ & $>400$ & $228.48 \pm 0.48$ & $309.09 \pm 0.06$ & $N^{f}$ \\
\hline & & LH & $337.62 \pm 1.25$ & $387.75 \pm 1.42$ & $255.72 \pm 0.77$ & $>400$ & $\mathrm{NA}^{\mathrm{f}}$ \\
\hline & \multirow{3}{*}{$\begin{array}{l}\text { Ethyl } \\
\text { Acetate }\end{array}$} & APEA & $124.03 \pm 1.40$ & $179.04 \pm 1.16$ & $60.14 \pm 2.18$ & $117.30 \pm 0.02$ & $20.20 \pm 1.77$ \\
\hline & & FEA & $45.61 \pm 1.28$ & $>400$ & $57.22 \pm 1.66$ & $300.00 \pm 0.12$ & $27.45 \pm 1.25$ \\
\hline & & LEA & $48.16 \pm 1.35$ & $>400$ & $45.87 \pm 1.24$ & $315.38 \pm 0.04$ & $16.30 \pm 1.16$ \\
\hline & \multirow{3}{*}{ Methanol } & APM & $46.35 \pm 1.12^{\mathrm{b}}$ & $188.07 \pm 0.31$ & $62.57 \pm 2.23$ & $44.57 \pm 0.12$ & $8.56 \pm 1.71$ \\
\hline & & FM & $43.45 \pm 1.63^{\mathrm{b}}$ & $72.78 \pm 1.23$ & $82.54 \pm 0.95$ & $23.70 \pm 0.06$ & $7.21 \pm 1.13$ \\
\hline & & LM & $48.80 \pm 1.84^{\mathrm{b}}$ & $398.61 \pm 0.46$ & $20.01 \pm 0.63$ & $49.78 \pm 0.06$ & $8.61 \pm 1.69$ \\
\hline & \multirow{3}{*}{ Butanol } & $\mathrm{APB}$ & $250.20 \pm 1.12$ & $51.17 \pm 0.28$ & $261.95 \pm 1.33$ & $15.47 \pm 0.05$ & $8.27 \pm 1.25$ \\
\hline & & FB & $>400$ & $35.64 \pm 1.15$ & $158.72 \pm 1.06$ & $12.77 \pm 0.04$ & $10.98 \pm 0.25$ \\
\hline & & LB & $245.90 \pm 1.38$ & $45.62 \pm 2.07$ & $>400$ & $10.22 \pm 0.06$ & $16.73 \pm 1.69$ \\
\hline & \multirow{3}{*}{ Standards } & $\begin{array}{l}\text { a- } \\
\text { tocopherold }\end{array}$ & $2.10 \pm 0.08$ & $37.20 \pm 0.41$ & $38.51 \pm 0.54$ & $66.72 \pm 0.81$ & $\mathrm{NT}$ \\
\hline & & $\mathrm{BHA}^{\mathrm{d}}$ & $1.34 \pm 0.04$ & $19.80 \pm 0.36$ & $11.82 \pm 0.09$ & $24.40 \pm 0.69$ & $\mathrm{NT}^{\mathrm{e}}$ \\
\hline & & EDTA $^{d}$ & $\mathrm{NT}^{\mathrm{e}}$ & $\mathrm{NT}^{\mathrm{e}}$ & $\mathrm{NT}^{\mathrm{e}}$ & $\mathrm{NT}^{\mathrm{e}}$ & $94.70 \pm 0.60$ \\
\hline
\end{tabular}

a IC $_{50}$ values represent the means \pm SEM of three parallel measurements $(p<0.05)$. b $\%$ inhibition of $400 \mu \mathrm{g} / \mathrm{mL}$ concentration of extracts. ${ }^{c} A_{0.50}$ values represent the means \pm SEM of three parallel measurements $(p<0.05)$. ${ }^{d}$ Reference compounds. ${ }^{\mathrm{e}} \mathrm{NT}$ : not tested. ${ }^{\mathrm{f}}$ NA: not active. AP: Aerial part; F: Flower part; L: Leaves part.

Table 3. Anticholinesterase activities of the essential oil and extracts of aerial, flower and leaves parts of Erica manipuliflora a.

\begin{tabular}{|c|c|c|c|c|}
\hline \multicolumn{5}{|c|}{ Anticholinesterase Activity } \\
\hline & & & $\begin{array}{l}\text { AChE assay } \\
\mathrm{IC}_{50}(\mu \mathrm{g} / \mathrm{mL})\end{array}$ & $\begin{array}{c}\text { BChE assay } \\
\mathrm{IC}_{50}(\mu \mathrm{g} / \mathrm{mL})\end{array}$ \\
\hline \multirow{16}{*}{$\begin{array}{l}\text { Erica } \\
\text { manipuliflora }\end{array}$} & \multirow{3}{*}{ Essential oil } & APEs & $144.87 \pm 1.39$ & $>400$ \\
\hline & & FEs & $79.19 \pm 0.95$ & $205.88 \pm 1.39$ \\
\hline & & LEs & $73.82 \pm 1.36$ & $118.02 \pm 1.17$ \\
\hline & \multirow{3}{*}{ Hexane } & $\mathrm{APH}$ & $338.05 \pm 2.79$ & $>400$ \\
\hline & & $\mathrm{FH}$ & $252.12 \pm 2.19$ & $283.42 \pm 0.62$ \\
\hline & & $\mathrm{LH}$ & $>400$ & $>400$ \\
\hline & \multirow{3}{*}{ Ethyl acetate } & APEA & $248.61 \pm 1.15$ & $79.66 \pm 1.79$ \\
\hline & & FEA & $>400$ & $146.54 \pm 1.97$ \\
\hline & & LEA & $284.32 \pm 1.81$ & $153.89 \pm 1.28$ \\
\hline & \multirow{3}{*}{ Methanol } & $\mathrm{APM}$ & $>400$ & $58.01 \pm 1.28$ \\
\hline & & FM & $281.81 \pm 1.25$ & $137.01 \pm 1.35$ \\
\hline & & LM & $>400$ & $351.94 \pm 1.13$ \\
\hline & \multirow{3}{*}{ Butanol } & $\mathrm{APB}$ & $>400$ & $263.04 \pm 1.75$ \\
\hline & & FB & $238.61 \pm 0.83$ & $99.91 \pm 1.12$ \\
\hline & & LB & $310.43 \pm 1.12$ & $>400$ \\
\hline & Standard & Galantamine $^{b}$ & $5.04 \pm 0.15$ & $50.80 \pm 0.93$ \\
\hline
\end{tabular}

a $\mathrm{IC}_{50}$ values represent the means \pm SEM of three parallel measurements $(p<0.05) .{ }^{\mathrm{b}}$ Reference compound. ${ }^{\mathrm{c}}$ NA: Not active. AP: Aerial part; F: Flower part; L: Leaves part. 
Currently, using of cholinesterase inhibitors and the increase in the level of acetylcholine is the most commonly used method for treatment of AD. Inhibition of acetylcholinesterase (AChE) and butyrylcholinesterase $(\mathrm{BChE})$ enzymes that hydrolyse acetylcholine prevents the progression of the disease.

Table 3 shows $\mathrm{IC}_{50}$ values of the aerial, flower and leaves parts of essential oil, and extracts of $E$. manipuliflora for $\mathrm{AChE}$ and $\mathrm{BChE}$ assays. The leaves part of essential oil $\left(\mathrm{IC}_{50}: 73.82 \pm 1.36 \mu \mathrm{g} / \mathrm{mL}\right.$ ) exhibited moderate inhibitory activity against $\mathrm{AChE}$, followed by the flower part of essential oil $\left(\mathrm{IC}_{50}: 79.19 \pm 0.95\right.$ $\mu \mathrm{g} / \mathrm{mL}$ ). Against BChE enzyme, the aerial parts of methanol and ethyl acetate extracts showed the highest inhibitory activity with $\mathrm{IC}_{50}$ values of $58.01 \pm 1.28 \mu \mathrm{g} / \mathrm{mL}$ and $79.66 \pm 1.79 \mu \mathrm{g} / \mathrm{mL}$, respectively. In the literature survey, no study was found related to anticholinesterase activity of E. manipuliflora.

\section{CONCLUSION}

In this study, the chemical composition of essential oils of the aerial, flower and leaves parts of $E$. manipuliflora which is widely grown in Western Anatolia were reported here for the first time. In addition, this study represents the first comprehensive investigation on antioxidant and anticholinesterase activities of essential oils and extracts of various parts of E. manipuliflora. E. manipuliflora which is an important source of pollen for apiculture in pine honey production periods can be considered as a potential source of natural antioxidant and cholinesterase enzyme inhibitor. Thus, further studies are necessary to isolate and identify the bioactive components from these species. We believe that it is important to convert this source to medical products by performing in vivo tests.

\section{MATERIALS AND METHODS}

\subsection{Plant material}

The aerial, flower and leaves parts of Erica manipuliflora were collected from Ula-Muğla, Turkey in 2017. The voucher specimen has been deposited at the herbarium of Natural Product Laboratory of Muğla Sitkı Koçman University.

\subsection{Extraction}

The aerial, flower and leaves parts of E. manipuliflora were extracted separately with hexane, ethyl acetate, methanol, and butanol respectively at room temperature for $24 \mathrm{~h}$ and four times. Solvents were removed with a rotary evaporator. All extracts were stored at $+4^{\circ} \mathrm{C}$ until analysis.

\subsection{Isolation of the essential oil}

The essential oils of aerial, flower and leaves parts of E. manipuliflora were obtained via hydrodistillation in a Clevenger type apparatus for $4 \mathrm{~h}$. The oils were dried over anhydrous sodium sulphate and stored under $+4^{\circ} \mathrm{C}$ until analyses.

\subsection{Analysis of the essential oil}

\subsubsection{Gas chromatography (GC-FID)}

A Flame Ionization Detector (FID) and a DB-5 fused silica capillary non-polar column ( $30 \mathrm{~m} \times 0.25 \mathrm{id}$., film thickness $0.25 \mu \mathrm{m}$ ) were used for GC analyses. The injector temperature and detector temperature were adjusted $250{ }^{\circ} \mathrm{C}$ and $270{ }^{\circ} \mathrm{C}$, respectively. Carrier gas was He at a flow rate of $1.4 \mathrm{~mL} / \mathrm{min}$. Sample size was $1.0 \mu \mathrm{L}$ with a split ratio of 20:1. The initial oven temperature was held at $60^{\circ} \mathrm{C}$ for $5 \mathrm{~min}$, then increased up to $240^{\circ} \mathrm{C}$ with $4{ }^{\circ} \mathrm{C} / \mathrm{min}$ increments and held at this temperature for $10 \mathrm{~min}$. The percentage composition of the essential oil was determined with GC solution computer program.

\subsubsection{Gas chromatography/mass spectrometry (GC/MS)}

An Ion trap MS spectrometer and a DB-5 MS fused silica non-polar capillary column $(30 \mathrm{~m} \times 0.25 \mathrm{~mm}$ ID, film thickness $0.25 \mu \mathrm{m}$ ) were used for the GC/MS analyses. Carrier gas was helium at a flow rate of 1.4 $\mathrm{mL} / \mathrm{min}$. The oven temperature was held at $60^{\circ} \mathrm{C}$ for $5 \mathrm{~min}$, then increased up to $240{ }^{\circ} \mathrm{C}$ with $4{ }^{\circ} \mathrm{C} / \mathrm{min}$ increments and held at this temperature for $10 \mathrm{~min}$. Injector and MS transfer line temperatures were set at 220 ${ }^{\circ} \mathrm{C}$ and $290^{\circ} \mathrm{C}$, respectively. Ion source temperature was $200^{\circ} \mathrm{C}$. The injection volume was $0.2 \mu \mathrm{L}$ with a split ratio of 1:20. EI-MS measurements were taken at $70 \mathrm{eV}$ ionization energy. Mass range was from $\mathrm{m} / \mathrm{z} 28$ to 650 amu. Scan time $0.5 \mathrm{~s}$ with 0.1 inter scan delays. Identification of components of the essential oils was based on GC retention indices and computer matching with the Wiley, NIST-2005 and TRLIB Library as well as by 
comparison of the fragmentation patterns of the mass spectra with those reported in the literature [31] and whenever possible, by co-injection with authentic compounds.

\subsection{Antioxidant activity}

The total antioxidant activity of the extracts and essential oils of aerial, flower and leaves parts of $E$. manipuliflora was tested by $\beta$-carotene-linoleic acid test system as previously reported paper [32]. Radical scavenging activities were measured by DPPH free and ABTS cation radical scavenging assays [32]. Reducing powers were evaluated by CUPRAC assays [32]. Metal chelating activity on ferrous ions was determined according to our described method in the literature [33]. The sample concentration providing $50 \%$ inhibition activity $\left(\mathrm{IC}_{50} \mu \mathrm{g} / \mathrm{mL}\right.$ ) was calculated from the graph of antioxidant activity percentages (Inhibition \%) against sample concentrations $(\mu \mathrm{g} / \mathrm{mL})$. The sample concentration having 0.50 absorbance $\left(\mathrm{A}_{0.5}\right)$ was calculated from the plot of CUPRAC absorbance against sample concentration.

\subsection{Anticholinesterase activity}

Anticholinesterase activities of three parts of E. manipuliflora were measured the spectrophotometric method developed by Ellman et al. [34]. Galantamine was used as reference compound. The results were given as $50 \%$ inhibition activity $\left(\mathrm{IC}_{50} \mu \mathrm{g} / \mathrm{mL}\right)$.

\subsection{Statistical analysis}

All data on the antioxidant and anticholinesterase activities were the mean of three parallel sample measurements. The data were recorded as the average \pm S.E.M (Standard error meaning). Significant differences between the means were determined by student's $t$ test, and $p$ values $<0.05$ were regarded as significant.

Author contributions: Concept - Ç.K., G.T.Ç., M.E.D.; Design - G.T.Ç., M.E.D.; Supervision - G.T.Ç., M.E.D.; Materials - Ç.K., M.E.D.; Data Collection and/or Processing - Ç.K., M.E.D.; Analysis and/or Interpretation - Ç.K., M.T., S.K., G.T.Ç., M.E.D.; Literature Search - Ç.K., G.T.Ç., M.E.D.; Writing - G.T.Ç., M.E.D.; Critical Reviews - Ç.K., M.T., S.K., G.T.Ç., M.E.D.

Conflict of interest statement: The authors declared no conflict of interest.

\section{REFERENCES}

[1] Mitic VD, Ilic MD, Stankov-Jovanovic VP, Stojanovic GS, Dimitrijevic MV. Essential oil composition of Erica spiculifolia Salisb-first report. Nat Prod Res. 2018; 32(2): 222-224. [CrossRef]

[2] Dias P, Martins A, Figueiredo AC, Rauter AP. Flower Colour and Essential oil composition in Erica australis L. Grown in Portugal. J Essent Oil Bear Pl. 2016; 19(4): 1013-1018. [CrossRef]

[3] Akkol EK, Yeşilada E, Güvenç A. Valuation of anti-inflammatory and antinociceptive activities of Erica species native to Turkey. J Ethnopharmacol. 2008; 116(2): 251-257. [CrossRef]

[4] Oliver EGH. Systematics of Ericeae (Ericaceae: Ericoideae) species with indehiscent and partially dehiscent fruits. Contrib Bolus Herb. 2000; 9:1-483.

[5] Nelson EC. The original material of two Turkish species of Erica (Ericaceae) described and named by Richard Anthony Salisbury (1761-1829). Turk J Bot. 2007; 31(5): 463-466.

[6] Stevens PF. Erica L. In: Davis PH (Ed). Flora of Turkey and the East Aegean Islands, Vol. 6, Edinburgh University Press, Edinburgh, 1978, pp. 95-97.

[7] Güvenç A, Kendir G. The leaf anatomy of some Erica taxa native to Turkey. Turk J Bot. 2012; 36(3): 253-262. [CrossRef]

[8] Sadki C, Hacht B, Souliman A, Atmani F. Acute diuretic activity of aqueous Erica multiflora flowers and Cynodon dactylon rhizomes extracts in rats. J Ethnopharmacol. 2010; 128(2): 352-356. [CrossRef]

[9] Reyes RM, Martin-Cordero C, Ayuso Gonzalez MJ, Toro Sainz MV, Alarcon de la Lastra C. Antiulcer activity in rats by flavonoids of Erica andevalensis Cabezudo-Rivera. Phytother Res. 1996; 10(4): 300-303. [CrossRef]

[10] Santos A, Luís Â, Ferreira S, Duarte AP. Antioxidant and antimicrobial activity and potential of heather (Erica spp.) extracts in the control of Listeria monocytogenes. Int J Food Sci Tech. 2019; 54(3): 862-870. [CrossRef] 
[11] Guendouze-Bouchefa N, Madani K, Chibane M, Boulekbache-Makhlouf L, Hauchard D, Kiendrebeogo M, Stevigny C, Okusa PN, Duez P. Phenolic compounds, antioxidant and antibacterial activities of three Ericaceae from Algeria. Ind Crops Prod. 2015; 70: 459-466. [CrossRef]

[12] Veličković V, Đurović S, Radojković M, Cvetanović A, Švarc-Gajić J, Vujić J, Trifunović S, Mašković PZ. Application of conventional and non-conventional extraction approaches for extraction of Erica carnea L.: Chemical profile and biological activity of obtained extracts. J Supercrit Fluid. 2017; 128: 331-337. [CrossRef]

[13] Nunes R, Rodrigues S, Pasko P, Tyszka-Czochara M, Grenha A, Saraiva de Carvalho I. Effect of Erica australis extract on Caco-2 cells, fibroblasts and selected pathogenic bacteria responsible for wound infection. Ind Crops Prod. 2014; 52: 99-104. [CrossRef]

[14] Ertürk Ö. Antibacterial and antifungal activity of ethanolic extracts from eleven spice plants. Biologia. 2006; 61(3): 275-278. [CrossRef]

[15] Şen B, Kessler S, Gurdal B, Kiemer A, Mat A. The difference between the extracts of Erica manipuliflora in flowering and fruiting periods in terms of the cytotoxic effects. J Fac Pharm. 2016; 46(2): 71-78.

[16] Pavlović RD, Lakusićć B, Doslov-Kokorus Z, Kovacević N. Arbutin content and antioxidant activity of some Ericaceae species. Pharmazie. 2009; 64(10): 656-659. [CrossRef]

[17] Márquez-García B, Córdoba F. Antioxidative system in wild populations of Erica andevalensis. Environ Exp Bot. 2010; 68(1): 58-65. [CrossRef]

[18] Márquez-García B, Horemans N, Cuypers A, Guisez Y, Córdoba F. Antioxidants in Erica andevalensis: A comparative study between wild plants and cadmium-exposed plants under controlled conditions. Plant Physiol Bioch. 2011; 49(1): 110-115. [CrossRef]

[19] Márquez-García B, Fernández-Recamales M, Córdoba F. Effects of Cadmium on Phenolic Composition and Antioxidant Activities of Erica andevalensis. J Bot. 2012. [CrossRef]

[20] Nogués I, Peñuelas, J, Llusià J, Estiarte M, Munné-Bosch S, Sardans J, Loreto F. Physiological and antioxidant responses of Erica multiflora to drought and warming through different seasons. Plant Ecol. 2012; 213(4): 649-661. [CrossRef]

[21] Nazemiyeh H, Bahadori F, Delazar A, Ay M, Topçu G, Kolak U, Nahar L, Auzie AA, Sarker SD. Tricetin Tricetin 4'O-a-L-rhamnopyranoside: A new flavonoid from the aerial parts of Erica arborea. Chem Nat Compd. $2008 ; 44(2): 174$. [CrossRef]

[22] Martin-Cordero C, Reyes M, Ayuso MJ, Toro V. Cytotoxic Triterpenoids from Erica andevalensis. Z Naturforsch C. 2001; 56(1-2): 45-48. [CrossRef]

[23] Ballester A, Verwey A, Ovbreem JC. 2-Hydroxyphenylacetic acid and 2, 4-dihydroxyphenyl acetonitrile from Erica scoparia. Phytochem. 1975; 14(7): 1667-1668. [CrossRef]

[24] Bennini B, Chulia AJ, Kaouadji M, Delage C. (2R,3R)-Dihydroflavonol aglycone and glycosides from Erica cinerea. Phytochem. 1993; 33(5): 1233-1236. [CrossRef]

[25] Chulia AJ, Benini B, Kaouadji M, Allais DP, Delage C. Two Flavonol Conjugates from Erica cinerea. J Nat Prod. 1995; 58(4): 560-563. [CrossRef]

[26] Crowden RK, Jarman JR. Anthocyanins in the genus Erica. Phytochem. 1976; 15(11): 1796-1797. [CrossRef]

[27] Méndez J. Isofraxidin in Erica flowers. Phytochem. 1978; 17(4): 820. [CrossRef]

[28] Vieitez E, Ballester A. Phenolic and coumaric components in Erica cinerea. Anales Inst Bot Cavanilles. 1972; 29: 129142.

[29] Tzitsa E, Tzakou O, Loukis A. Volatile constituents of Erica manipuliflora Salisb. from Greece. J Essent Oil Res. 2000; 12(1): 67-68. [CrossRef]

[30] Köroğlu A, Hürkul MM, Kendir G, Küçükboyacı N. In vitro antioxidant capacities and phenolic contents of four Erica L. (Ericaceae) taxa native to Turkey. J Res Pharm. 2019; 23(1): 093-100. [CrossRef]

[31] Adams RP, Identification of essential oil components by Gas Chromatography/Mass Spectrometry., fourth ed., Allured Publ. Corp, Carol Stream, IL, USA 2007.

[32] Tel G, Apaydın M, Duru ME, Öztürk M. Antioxidant and Cholinesterase Inhibition Activities of three Tricholoma Species with Total Phenolic and Flavonoid Contents: The Edible Mushrooms from Anatolia. Food Anal Method. 2012; 5(3): 495-504. [CrossRef] 
[33] Çayan F, Tel G, Duru ME, Öztürk M, Türkoğlu A, Harmandar M. Application of GC, GC-MSD, ICP-MS and Spectrophotometric Methods for the Determination of Chemical Composition and In Vitro Bioactivities of Chroogomphus rutilus: The Edible Mushroom Species. Food Anal Method. 2014; 7(2): 449-458. [CrossRef]

[34] Ellman GL, Courtney KD, Andres Jr V, Featherston RM. A new and rapid colorimetric determination of acetylcholinesterase activity. Biochem Pharmacol. 1961; 7(2): 88-90. [CrossRef]

This is an open access article which is publicly available on our journal's website under Institutional Repository at http://dspace.marmara.edu.tr. 